\title{
Evaluasi Penyusunan Indikator Kinerja Studi Pada Dinas Pendidikan Nasional Kabupaten Sumbawa
}

\author{
Mujibur Rahmat* dan Rusdi Akbar, M.Sc., Ph.D., CMA., Ak., CA. \\ Program Magister Akuntansi, Fakultas Ekonomika dan Bisnis, Universitas Gadjah Mada \\ *Corresponding author.
}

\begin{abstract}
ABSTRAK
Pengukuran kinerja dapat digunakan sebagai dasar untuk menilai keberhasilan dan kegagalan pelaksanaan program/kegiatan sesuai dengan sasaran dan tujuan yang telah ditetapkan dalam rangka mewujudkan visi dan misi. Penelitian ini membahas tentang evaluasi penyusunan indikator kinerja Dinas Pendidikan Nasional Kabupaten Sumbawa dengan pendekatan Ongoing Performance Measurement and Management (OPM\&M). Tujuan penelitian ini untuk mengetahui kesesuaian indikator kinerja Dinas Pendidikan Nasional Kabupaten Sumbawa serta menjelaskan indikator kinerja program/kegiatan dalam mendukung pencapaian kinerja Dinas Pendidikan Nasional Kabupaten Sumbawa dengan pendekatan OPM\&M.

Pendekatan OPM\&M dapat digunakan untuk mengukur kualitas indikator kinerja yang disusun dan dilaporkan oleh Dinas Pendidikan Nasional Kabupaten Sumbawa dengan menggunakan dua alat yakni Logic Model dan analisis empat kuadran Friedman. Metode penelitian dilakukan dengan menganalisis data dan mengkonfirmasikannya melalui wawancara.

Hasil penelitian menunjukan bahwa indikator kinerja Dinas Pendidikan Nasional Kabupaten Sumbawa telah menunjukkan kesesuaian informasi yang logis dari dokumen perencanaan hingga pelaporannya. Analisis dengan model cetak biru kinerja menunjukkan bahwa sebagian besar indikator kinerja program utama/kegiatan Dinas Pendidikan Nasional Kabupaten Sumbawa berorientasi output/aktivitas (service-delivery outcome) dan belum berorientasi hasil/manfaat yang dapat dirasakan oleh masyarakat (Community Outcome).
\end{abstract}

Kata kunci: Pengukuran kinerja; indikator kinerja; laporan akuntabilitas kinerja (LAKIP), Logic Model, Pendekatan OPM\&M, Model Cetak Biru Kinerja, analisis empat kuadran, New Public Management (NPM) 


\section{PENDAHULUAN}

Semenjak diterbitkannya Instruksi Presiden Nomor 7 tahun 1999 tentang Akuntabilitas Kinerja Instansi pemerintah (AKIP), akuntabilitas kinerja instansi pemerintah mulai mendapat perhatian. Peraturan ini mewajibkan setiap instansi pemerintah untuk melaporkan kinerjanya dalam bentuk LAKIP (Laporan Akuntabilitas Kinerja Instansi Pemerintah).

Meskipun penerapan peraturan tentang akuntabilitas kinerja pada instansi pemerintah sudah dilaksanakan, tetapi pada kenyataannya penilaian kinerja pada instansi pemerintah menghadirkan konsekuensi yang tidak diharapkan. Thiel dan Leeuw (2002) menyatakan bahwa terdapat konsekuensi yang tidak diharapkan seperti kenaikan biaya monitoring, implementasi kebijakan meningkatkan tekanan yang dapat menyebabkan pengaruh disfungsional seperti sifat kaku, kurangnya inovasi, dan suboptimisasi. Selain itu, beberapa bukti menunjukkan monitoring akan mengakibatkan perilaku simbolis agar terlihat bagus dari segi penampilan saja, tetapi pada kenyataannya tidak seperti itu.

Untuk menilai kinerja instansi pemerintah sekaligus memperbaiki kualitas dalam pengambilan keputusan di masa mendatang, penyusunan LAKIP sangat diperlukan. Akan tetapi, pada kenyataannya penyusunan laporan kinerja dinilai lebih disebabkan adanya peraturan yang mewajibkan pemerintah untuk membuatnya bukan karena kesadaran akan arti pentingnya laporan itu bagi peningkatan kinerja instansi pemerintah yang bersangkutan (Akbar, et. al, 2012; sadjiarto, 2000).

Kesadaran pemerintah daerah untuk memperbaiki kualitas LAKIP sepertinya masih kurang jika dibandingkan dengan keinginan mereka untuk mendapat opini Wajar Tanpa Pengecualian dari Badan Pemeriksa Keuangan. Dalam pengukuran kinerja yang meliputi ukuran kinerja finansial dan non finansial, instansi pemerintah perlu menggunakan berbagai indikator kinerja untuk menilai keefektifan kualitas pelayanan pemerintah (Kelly \& Swindell, 2002). Instansi pemerintah akan menyajikan laporan keuangan yang ambigu, tidak relevan, kurang terpercaya dan kurang dapat dipertanggungjawabkan apabila instansi pemerintah hanya menggunakan indikator kinerja finanial semata, karena laporan keuangan cenderung mudah dimanipulasi (Pilcher, 2005).

Dinas Pendidikan Nasional Kabupaten Sumbawa merupakan salah satu unsur pelaksana pemerintahan daerah yang mempunyai tugas melaksanakan urusan pemerintahan daerah di bidang pendidikan dan perpustakaan. Dinas Pendidikan Nasional Kabupaten Sumbawa dalam melaksanakan tugasnya masih terkendala masalah dalam penyempurnaan rumusan sasaran dan indikator kinerja dari perencanaan strategis sampai pelaporan kinerja. Jika hal ini terus dibiarkan maka indikator kinerja yang ditetapkan tidak dapat menunjukkan keberhasilan dan kegagalan pelaksanaan pengelolaan dan penyelenggaraan pendidikan yang dapat dirasakan oleh masyarakat.

Secara umum, hal ini mungkin disebabkan oleh lemahnya penyusunan dokumen perencanaan. Kelemahan ini tentu saja akan membawa dampak yang besar terhadap siklus selanjutnya. Dokumen perancanaan yang disusun tidak memuat sasaran dan indikator kinerja. Ketiaadaan indikator penilaian kinerja dan target yang ditetapkan adalah hal yang paling krusial dalam penilaian akuntabilitas instansi pemerintah. Proses akuntabilitas tidak mungkin bisa dilaksanakan jika instansi pemerintah tidak menetapkan apa yang ingin dicapai dengan indikator kinerja yang obyektif dan terukur.

Tujuan dari penelitian ini adalah untuk Mengevaluasi kesesuaian informasi yang logis indikator kinerja Dinas Pendidikan Nasional Kabupaten Sumbawa dalam sistem akuntabilitas kinerja instansi pemerintah serta menjelaskan indikator kinerja yang digunakan sebagai ukuran kesuksesan dalam mencapai sasaran kinerja dengan pendekatan cetak biru kinerja.

\section{TINJAUAN PUSTAKA}

Perubahan konsep NPM menyebabkan perubahan model manajemen sektor publik yang kaku, birokratis, dan hierarkis menjadi model manajemen sektor publik yang fleksibel dan lebih mengakomodir pasar. Perubahan tersebut juga telah mengubah peran pemerintah terutama dalam 
hal hubungan antara pemerintah dengan masyarakat (Hughes, 1998). Crishtopher Hood (1991) mengemukakan tujuh komponen utama konsep NPM antara lain:

a. Manajemen profesional di sektor publik.

b. Adanya standar kinerja dan ukuran kinerja.

c. Penekanan yang lebih besar terhadap pengendalian output dan outcome.

d. Pemecahan unit-unit kerja di sektor publik.

e. Menciptakan persaingan di sektor publik.

f. Pengadopsian gaya manajemen di sektor bisnis ke dalam sektor publik.

g. Penekanan pada disiplin dan penghematan yang lebih besar dalam menggunakan sumber daya.

Akuntabilitas adalah kewajiban untuk memberikan pertanggungjawaban atau menjawab dan menerangkan kinerja dan tindakan seseorang / badan hukum / pimpinan suatu organisasi kepada pihak yang memiliki hak atau yang berkewenangan untuk meminta keterangan atau pertanggungjawaban (LAN, 2004).

Pengertian evaluasi menurut Peraturan Pemerintah Nomor 39 tahun Tahun 2006 adalah rangkaian kegiatan yang membandingkan realisasi masukan (input), keluaran (output), dan hasil (outcome) terhadap rencana dan standar. Kinerja merupakan gambaran mengenai tingkat pencapaian pelaksanaan suatu program/kegiatan/kebijaksanaan dalam mewujudkan sasaran, tujuan, misi dan visi organisasi yang tertuang dalam perumusan skema strategis suatu organisasi (Bastian, 2006).

Menurut Bastian (2006), indikator kinerja adalah ukuran kuantitatif dan/atau kualitatif yang menggambarkan tingkat pencapaian suatu kegiatan dan sasaran yang telah ditetapkan, dengan memperhitungkan indikator masukan (input), keluaran (output), hasil (outcome), manfaat (benefit), dan dampak (impact). Salah satu model evaluasi dalam pengukuran kinerja yang banyak dan lazim digunakan adalah Model Alur Logika (Logic Model). McLaughlin (1999) mengatakan bahwa Logic Modeladalah suatu alat yang sudah digunakan oleh para manajer dan evaluator selama lebih dari 20 tahun untuk menjelaskan efektivitas dari program mereka.

Logic Model diawali dengan melihat situasi yang terjadi pada sebuah organisasi, lalu menetapkan situasi apa yang ingin diubah, setelah menetapkan situasi yang ingin diubah kemudian mencari prioritas yang diutamakan untuk mengubah situasi tersebut, setelah itu bisa ditetapkan program dan kegiatan yang ingin digunakan untuk mencapai situasi yang diinginkan. Untuk menggelar kegiatan tersebut sebelumnya dibutuhkan masukan yang di dalamnya terdiri dari seluruh sumber daya yang mampu digunakan oleh organisasi, setelah itu nantinya akan menghasilkan output yang akan berdampak pada perubahan situasi (outcome) pada organisasi. Secara singkat dapat diartikan Logic Model adalah peta (map) dari cara berpikir dengan logika dalam menyusun atau memformulasikan kebijakan, program, inisiatif maupun kegiatan. Berikut gambar standar Logic Modelyang diambil dari sumber Ohio Universiy.

Model pengukuran yang digunakan dalam penelitian ini adalah model logika dengan pendekatan OPM\&M (Ongoing Performance Measurement and Management). OPM\&M merupakan pendekatan evaluasi dan perencanaan yang komprehensif dengan menggunakan model logika inovatif dan perluasan, yang dikenal dengan nama Performance Blueprint. Model ini dikembangkan oleh DR. Paul J.Longo untuk digunakan APWR sejak tahun 1998. APWR merupakan program bantuan teknis dan riset terapan yang didanai oleh Departemen Tenaga Kerja dan Layanan Keluarga Ohio dan Ohio University (Ohio, 2002).

Dalam pendekatan OPM\&M juga mengkolaborasikan pendakatan empat kuadran milik Friedman (2000) untuk mengidentifikasi kualitas indikator kinerja dengan membagi kualitas indikator kinerja ke dalam empat bagian yakni upaya dan hasil serta terbagi atas kuantitas dan kualitas. Menurut Friedman (2005) bahwa semua sistem akuntabilitas kinerja ditetapkan dengan cara ukuran (indikator) dan kualitas dari upaya dan hasil. 


\section{METODE PENELITIAN}

Penelitian ini menggunakan metode kualitatif dengan desain studi kasus pada obyek penelitian. Metode penelitian kualitatif adalah metode penelitian yang digunakan untuk meneliti pada kondisi obyek yang alamiah dimana peneliti sebagai instrument kunci, teknik pengumpulan data dilakukan secara gabungan, analisis data bersifat induktif, dan hasil penelitian kualitatif lebih menekankan makna daripada generalisasi (Sugiyono, 2012). Desain studi kasus digunakan dalam penelitian ini karena desain penelitian ini ditujukan untuk memahami proses evaluasi dimana peneliti mengembangkan analisis secara mendalam pada kasus tentang suatu program, kejadian, aktivitas, proses atau individu (Creswell, 2014).

\section{Teknik Analisis Data}

Teknik analisis data yang digunakan dalam penelitian ini adalah analisis tematik. Analisis tematik adalah metode untuk mengidentifikasi, menganalisis, dan melaporkan pola-pola (tema) dalam data (Braun dan Clarke, 2006). Analisis tematik mengatur dan mendeskripsikan sekumpulan data menjadi data-data yang lebih terperinci.

Analisis dokumen dalam penelitian ini menggunakan model cetak biru kinerja yang merupakan gabungan model logika inovatif dan Pendekatan Empat Kuadran Friedman sehingga dapat dianalisis kesesuaian logis antara perencanaan sampai pelaporan kinerja yang berbasis pada hasil serta dapat mengkatagorikan kinerja Dinas Pendidikan Kabupaten Sumbawa ke dalam empat tipe pengukuran kinerja yaitu kuantitas upaya, kualitas upaya, kuntitas hasil, dan kualitas hasil.

Alat analisis yang digunakan dalam penelitian ini adalah cetak biru kinerja yang berisikan dua model berikut:

1. Logic ModelCetak Biru Kinerja

Dengan Logic Model dapat diketahui bagaimana suatu program bekerja dalam kondisi yang pasti untuk mengatasi permasalahan yang telah diidentifikasi. Model ini adalah alat pengukuran kinerja berdasarkan pendekatan Logic Model yang diperluas dan digunakan untuk menguji kesesuaian informasi indikator kinerja dalam dokumen perencanaan strategik yang dimiliki oleh Dinas Pendidikan Nasional Kabupaten Sumbawa.

Four Quadrant Analysis

Indikator kinerja dianalisis dengan menggunakan model analisis yang dikembangkan oleh Friedman yaitu four quadrant analysis.

\section{ANALISIS DAN DISKUSI}

Analisis kesesuaian informasi (hubungan yang logis) dilakukan dengan melihat konsistensi dan keterkaitan pada indikator kinerja sasaran maupun indikator kinerja program/kegiatan mulai dari dokumen perencanaan hinggal pelaporannya. Logic Modelmenjadi alat untuk menganalisis dua hal tersebut melalui dua pendekatan. Pendekatan pertama yaitu dengan menganalisis konsistensi indikatro kinerja mulai dari perencanaan hingga pelaporan. Pendekatan kedua dengan menganalisis keterkaitan atau hubungan antara indikator kinerja sasaran dengan indikator kinerja program/kegiatan.

Analisis konsistensi indikator kinerja sasaran mulai dari dokumen perencanaan hingga pelaporan, dilihat dengan membandingkan indikator kinerja sasaran pada dokumen Renstra, RKT, TAPKIN, dan LAKIP. Kemudian dilihat apakah indikator yang digunakan tidak berubah atau tiadak ada penambahan atau pengurangan indikator kinerja ataupun perubahan pernyataan dari indikator kinerja tersebut.

Dari hasil analisis tersebut kemudian diketahui bahwa indikator sasaran yang terdapat pada dokumen Renstra, RKT, TAPKIN, dan LAKIP telah menunjukkan konsistensi yaitu pernyataan masing-masing indikator kinerja tersebut sama, tidak ada perubahan, penambahan ataupun pengurangan dari dokumen perencanaan hingga pelaporannya, baik untuk tahun 2013 maupun 
2014. Hal ini menunjukkan bahwa Dinas Pendidikan Nasional Kabupaten Sumbawa dalam membuat pelaporan pencapaian indikator kinerja sasaran sudah mengacu pada dokumen perencanaannya.

Kemudian analisis selanjutnya dilakukan dengan melihat keterkaitan dari indikator kinerja sasaran dengan indikator kinerja program/kegiatan pendukungnya. Program dan kegiatan dilaksanakan sebagai upaya untuk mencapai sasaran strategis dalam pembangunan. Oleh karena itu, seharusnya pencapaian indikator kinerja program/kegiatan harus mendukung indikator kierja sasaran yang telah ditetapkan.

Setelah dianalisis dengan alur berpikir logis, maka terdapat beberapa ketidaksesuaian antara indikator kinerja sasaran dengan indikator kinerja kegiatan (Outcome). Kesimpulannya adalah bahwa dalam melaporkan kinerja, Dinas Pendidikan Nasional Kabupaten Sumbawa, telah mengacu pada dokumen perencanaanya. Namun, jika dilihat dengan alur berpikir logis, terdapat beberapa ketidaksesuaian pada indikator kinerja sasaran dan indikator kinerja program/kegiatan pendukungnya.

Dari hasil Analisis empat kuadran dapat dilihat bahwa target indikator kinerja pada tahun 2013 dan 2014 masih didominasi oleh capaian output, dan sangat sedikit target yang ukurannya berupa rasio atau pesentase. Menurut Friedman (2005) indikator kinerja yang baik dan menjadi prioritas utama yaitu yang targetnya dalam bentuk kualitas (satuan Rasio atau persentase). Hal ini berarti bahwa indikator kinerja Dinas Pendidikan Nasional Kabupaten Sumbawa dominan mengukur seberapa banyak layanan yang diberikan kepada masyarakat.

Dari data hasil wawancara dapat disimpulkan bahwa sebenarnya Dinas Pendidikan Nasional Kabupaten Sumbawa telah menyadari arti pentingnya penyusunan indikator kinerja bagi Dinas Pendidikan. Hasil wawancara juga menunjukan bahwa penyusunan indikator kinerja tidak hanya dilakukan oleh bagian Program saja, tetapi seluruh bagian dibawah koordinasi bagian program. Dalam penyusunan tersebut, indikator kinerja sasaran pada RPJMD juga menjadi indikator dalam Renstra Dinas Pendidikan Nasional Kabupaten Sumbawa. Hal ini memperkuat hasil analisis logic model yang menunjukkan kesesuaian informasi Dinas Pendidikan Nasional Kabupaten Sumbawa dari dokumen perencanaan hingga dokumen pelaporannya. Dalam wawancara tersebut juga dapat tergambarkan bagaimana pertimbangan utama dalam penyusunan indikator kinerja, yaitu SDM SKPD, sarana prasarana penunjang, dan kemampuan anggaran.

Dari hasil wawancara juga ditemukan setidaknya ada empat alasan yang menjadi kendala dalam penyusunan indikator kinerja di Dinas Pendidikan Nasional Kabupaten Sumbawa:

1. Penyusunan indikator kinerja belum tersosialisasi dengan baik.

2. Penyusunan indikator kinerja masih bersifat parsial.

3. Sumber daya belum memenuhi secara maksimal untuk menyusus indikator kinerja.

4. Kelengkapan data.

\section{KESIMPULAN DAN SARAN \\ Kesimpulan}

Setelah dilakukan analisis data dan pembahasan pada BAB IV, maka dari hasil analisis tersebut diperoleh beberapakesimpulan yaitu sebagai berikut:

a) Indikator kinerja Dinas Pendidikan Nasional Kabupaten Sumbawa telah menunjukkan kesesuaian informasi jika dilihat dari dokumen perencanaan hingga dokumen pelaporan. Namun jika dilihat dari kesesuaian antara indikator kinerja sasaran dengan indikator kinerja program/kegiatan maka akan menunjukkan adanya hubungan yang tidak logis. Masih terdapat indikator output/outcome program/kegiatan yang tidak tertampung dalam indikator sasaran yang ditetapkan dalam Renstra.

b) Hasil evaluasi berdasarkan model cetak biru kinerja dengan analisis empat kuadran menunjukkan bahwa sebagian besar indikator kinerja program/kegiatan Dinas Pendidikan Nasional Kabupaten Sumbawa masih menggunakan indikator output/aktivitas (service- 
delivery outcome) sebagai ukuran dan belum berorientasi pada hasil/manfaat yang dirasakan masyarakat (community outcome).

c) Kendala-kendala yang dihadapi dalam penyusunan indikator kinerja antara lain:

1) Penyusunan indikator kinerja belum tersosialisasi dengan baik.

2) Penyusunan indikator kinerja masih bersifat parsial.

3) Sumber daya belum memenuhi secara maksimal untuk menyusus indikator kinerja.

4) Kelengkapan data.

4. Penyusunan dan pelaporan indikator kinerja di Dinas Pendidikan Nasional Kabupaten Sumbawa masih bersifat normatif dan cenderung hanya untuk memenuhi syarat administrasi saja.

\section{Saran}

Berdasarkan kesimpulan yang telah diuraikan, maka penulisi menyarankan rekomendasi berikut, sebagai masukan untuk perbaikan dalam penyusunan indikator kinerja Dinas Pendidikan Nasional Kabupaten Sumbawa.

a) Dalam menyusun indikator kinerja Dinas Pendidikan Nasional Kabupaten Sumbawa sebaiknya menggukan kerangka berpikir logis (Logic Model) dengan performance blueprint sebagai alat bantu untuk meninjau ulang indikator kinerja yang telah disusun, apakah berorientasi hasil/manfaat yang dirasakan masyarakat, bukan berorientasi pada pelayanan semata. Selain itu performance blueprint juga dapat digunakan untuk melihat gambaran mengenai hubungan yang logis dalam perumusan indikator kinerja kegiatan mulai dari input, Program/kegiatan, output, hingga outcome.

b) Meningkatkan pemahaman SDM baik yang melakukan penyusunan indikator kinerja maupun yang menjalankan program/kegiatan dengan mengadakan pelatihan mengenai penyusunan indikator kinerja yang baik setiap lima tahun sekali.

c) Dinas Pendidikan Nasional Kabupaten Sumbawa sebaiknya mengalokasikan anggaran pada kegiatan penyusunan indikator kinerja, serta memperbaiki sistem pengumpulan data informasi kinerja terkait kesulitan dalam menentukan ukuran ketercapaian indikator kinerja. Hal ini dilakukan agar terciptanya efektivitas dalam penyusunan dan pengukuran indikator kinerja.

\section{DAFTAR PUSTAKA}

Akbar Rusdi, Robyn Pilcher, and Brian Perrin. 2012. Performance Measurement in Indonesia: The Case of Local Government. Pacific Accounting Review, 262-291.

Akbar Rusdi, Robyn Pilcher, and Brian Perrin. 2015. "Implementing Performance Measurement System: Indonesian Local Government Under Pressure”, Qualitative Research in Accounting \& Management, Vol. 12 Iss: 1, pp.3 - 33.

Bappenas dan Departemen Keuangan. 2009. Pedoman Reformasi Perencanaan dan Penganggaran. Bappenas dan Departemen Keuangan Republik Indonesia.

Bastian, Indra. 2006. Sistem Akuntansi Sektor Publik, Edisi 2, Jakarta: Salemba Empat.

Braun Virginia and Clarke Victoria. 2006. Using Thematic Analysis in Psychology. Qualitative Research in Psychology, 3 (2). pp. 77-101. ISSN 1478-0887.

Cresswell, Jhon Well. 2014. Research Design. Sage Publications, Inc.

DiMaggio Paul Joseph and Walter Woody Powell. 1983. The Iron Cage Revisited: Institutional Isomorphism and Collective Rationality in Organizational Fields. American Sociological Review 48:147-160.

Friedman, Mark. 2005. Trying Hard is not Good Enough. FPSI Publishing.

Hood, Christopher. 1991. A Public Management for All Season? Public Administration, 69 (Spring): 3-19 
Kelly, Janet \& Swindell David. 2002. A Multiple-Indicator Approach to Municipal Service Evaluation: Correlating Performance Measurement and Citizen Satisfactioin across Jurisdiction. Public Administration Review. Vol. 62, Proquest.pg. 610.

Kementerian Negara Pendayagunaan Aparatur Negara dan Reformasi Demokrasi. Peraturan Menteri Negara Pendayagunaan Aparatur Negara dan Reformasi Demokrasi Nomor 29 Tahun 2010 tentang Pedoman Penyusunan Penetapan Kinerja dan Pelaporan Akuntabilitas Kinerja Instansi Pemerintah.

Lembaga Administrasi Negara Republik Indonesia. 2004. Modul Sistem Akuntabilitas Kinerja Instansi Pemerintah. Edisi ke-2. LAN, Jakarta.

Longo, Paul John. 2004. Public Management Skill Workshop in Performance Measurement. Workbook 1 Januari 2004.

Mahmudi. 2010. Manajemen Keuangan Daerah. Jakarta, Penerbit Erlangga.

Mahmudi. 2013. Manajemen Kinerja Pemerintah Edisi Kedua. UPP STIM YKPN, Yogyakarta.

Mardiasmo. 2009. Akuntansi Sektor Publik, Penerbit Andi, Yogyakarta.

Marvin, Henry. 2012. Evaluasi Penyusunan Indikator Kinerja pada Pemerintah Kabupaten Bantul. Tesis S2, Universitas Gadjah Mada Yogyakarta, (tidak dipublikasikan).

McLaughlin John A and Jordan Gretchen. 1999. Logic Model: A Tool for 123 Telling your Program's Performance Story. Evaluation and Program Planning, Vol.22.No.1, Februari 1999.

Mwita, John Isaac 2000. Performance Management Model : A Systems-Based Approach to Public Service Quality. The International Journal of Public Sector Management, , Vol. 13, h. 19 - 32

Nurkhamid, Muhamad. 2008. Implementasi Inovasi Sistem Pengukuran Kinerja Instansi Pemerintah. Jurnal Akuntansi Pemerintah, Vol. 3, No. l, Oktober 2008: 45-76

Ohio Departement of Jon and Family Services and ILLARD, Ohio University. 2002. Setting Outcomes, Measuring Result, a workshop on performance Measurement. Makalah Workshop.

Pilcher, Robyn. 2005. Local government Financial Key Performance Indicators-not so relevant, reliable and accountable. International journal of Productivity and Performance Management, Vol. 54 pp. 451-467.

Republik Indonesia. 2002. Instruksi Presiden Nomor 7 Tahun 1999 Tentang Akuntabilitas Kinerja Instansi Pemerintah.

Riyadi dan Deddy Supriady Bratakusumah. 2004. Perencanaan pembangunan daerah: Strategi menggali potensi dalam mewujudkan otonomi daerah. Jakarta: PT Gramedia Pustaka Utama.

Satori, Dja'man dan Aan Komariah. 2008. Metodologi Penelitian Kualitatif. Bandung: Alfabeta.

Sugiyono. 2012. Memahami penelitian Kualitatif. Bandung: CV Alfabeta.

Sugiyono. 2014. Metode penelitian Manajemen. Bandung: CV Alfabeta.

Thiel Sandra Van and Leeuw Frans. 2002. The Performance Paradox in the Public Sector. Public Performance and Management Review, Vol. 25, No. 3, pp. 267-2. 